Article History:

Submitted:

8 December 2021

Reviewed:

6 January 2022

Edited:

18 January 2022

26 January 2022

Accepted:

26 January 2022

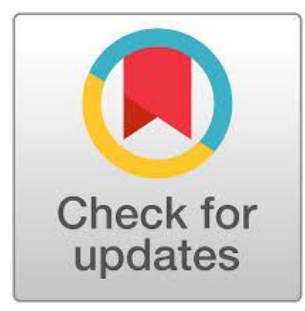

\section{Easy English Teaching in LEE Online Course}

\author{
Wenny Pratiwi ${ }^{*}$, Yeny Prastiwi \\ Universitas Muhammadiyah Surakarta, Indonesia \\ ${ }^{*}$ Corresponding author's email: \\ wennypratiwi962@gmail.com
}

DOI: https://doi.org/10.18196/ftl.v7i1.13317

\begin{abstract}
The Corona Virus Disease (Covid-19) pandemic at the end of 2019 made people study or work from home to prevent the spreading of the Corona Virus. It made WhatsApp (instant messaging app) gain the most significant number of users during the pandemic. Learning English Easy (LEE), one of the online courses in Indonesia, uses WhatsApp as the primary tool in their teaching-learning process. It gained thousands of student participants with varied cultural backgrounds during its first year. A high enthusiasm of the participants towards LEE online course made the researchers want to describe its implementation of the teachinglearning process and inform the students' perception about the LEE Online Course as an alternative solution during the pandemic. The data were collected from interviews, questionnaires, observation, and documentation. The total participants in this research were 397 students and two stakeholders of LEE. The data analysis technique was done using descriptive interpretive of TPACK framework by Mishra and Koehler (2006). Based on the data analysis, the great combination of three elements: technology, pedagogy, and content knowledge, which were implemented by LEE online course, could manage thousand of participants at one time, and it gave a great outcome based on the students' perception.
\end{abstract}

Keywords: Grammar; Online Course; Pandemic; WhatsApp 


\section{Introduction}

The Corona Virus Disease (Covid-19) pandemic changed people's lives worldwide from the end of 2019 up to the present. Many Governments issued the regulation to study or work from home to prevent the spreading of the Corona Virus, so did Indonesia. The situation forced everyone to count on technology. WhatsApp is the social media or instant messaging application that has experienced the most significant gains due to Covid-19. Burhan (2020) explained that amount of WhatsApp users during the pandemic in March 2020 increased by $40 \%$. It is caused by many schools and offices doing the activities through online platforms, especially WhatsApp. Barhoumi (2015) stated that WhatsApp is an instant messaging that provides several facilities such as allowing the users to exchange images, videos, voice notes, and text. They can create a group to discuss the material freely.

One online course that uses WhatsApp as the primary tool in their teaching-learning process is Learning English Easy (LEE). Based on the founder of LEE, Rhizki Amelia, LEE is a course that gives an additional course for senior high school and college students for free. This paper's meaning of 'course' is an additional hour for study outside the school hours. Until April 2021, 12 batches had been held on different topics, and thousands of participants from various cities around Indonesia had joined the LEE Online Course.

There have been studies that relate to the object of the study. The study of Susilo (2008) about WhatsApp use in the teaching and learning process showed that it could be used as an online tutor complements. The potentials come from its pedagogical, social, and technological affordances. The platform allowed the users to put up announcements, share ideas, resources, and open discussions from the pedagogical side. It helped the students to participate in giving feedback on the teaching-learning process. The features provided by WhatsApp also supported the students' pedagogical reconsidering (Conole \& Alevizou, 2010). The effectiveness of WhatsApp as an online platform was also proved by Barhoumi (2015). The online learning activities were done in a blended learning course. WhatsApp group, one of WhatsApp features, made the students active in discussing the questions based on the content taught. The interaction inside the WhatsApp group was beneficial and effective based on the survey and interview. It could increase the students' motivation to participate in the lecture's topic. WhatsApp use was examined as part, of course, gradable assignments and weekly pre and 
post-lecture discussions (Dahdal, 2020). WhatsApp in online learning claimed to be the most effective in and after Covid-19. It is stated that there is an increase in students' motivation based on the result of a questionnaire (Susilawati \& Supriyatno, 2020)

Based on the previous study, many types of research supported that technology was beneficial in the teaching-learning process. Moreover, all teaching-learning activities count on the technology in the Pandemy of Covid-19. In the study of Dong, Cao, and Li (2020), young children's parents were not ready for online learning because of its shortcoming. The lack of technological knowledge in online learning tools becomes the reason for the increased number of WhatsApp users for educational purposes because of its friendly use. The current study is interested in exploring its implementation. Many of the researchers in the previous studies did not explore the material or skill being taught. Therefore, it made its use in teaching-learning activities less evident in its implementation. In addition, the concept of the three elements, Technological, Pedagogical, and Content Knowledge, lacked the teacher's attention. Thus the researchers want to make it clear by describing the implementation of the teaching-learning process in an online course of Learning English Easy as an alternative solution during the pandemic. The researchers limited the topic to teaching grammar. To this end, the research questions of this study are as follows: 1 . How is the implementation of the teaching-learning process in the LEE Online Course? 2. What is students' perception of the LEE Online Course's teaching-learning process?

This paper contributes to teaching grammar through Technological, Pedagogical, and Content Knowledge in Online Course Learning English Easy. This paper provides the management of Online courses and the difficulties of their implementation. Then, based on the result of students' perception can improve the teachers' knowledge and quality as an English teacher about using the online platform. Also, they can prevent or find another alternative solution to the difficulties provided in this paper.

\section{Literature Review}

\section{WhatsApp}

WhatsApp is a free instant messaging application that counts on the internet connection (Robles, Guerrero, \& Montero, 2019). This application is available for Android 
IOS and other smartphones. It allows the users to share multimedia messages such as texts, photos, videos, documents, voice notes, and even phone calls or video calls. Because it uses the phone's internet connection, when the users send or receive any messages, they do not need to pay for every message or call. This free service is also valid when using it in other countries. WhatsApp was created by Jan Koum and Brian Acton in 2009. Both of them are from Yahoo (Jackson, 2012).

Figure 1. WhatsApp Appearance

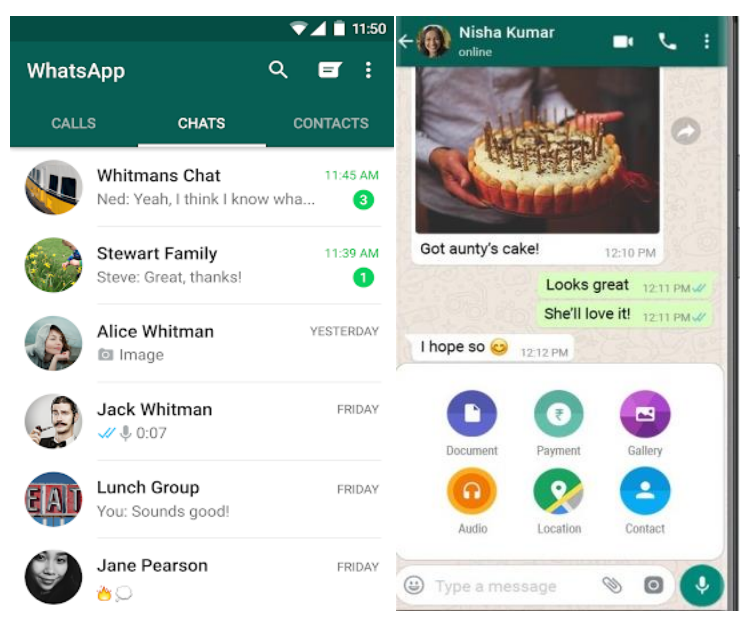

The researchers had collected several features and the benefit of its use based on Gon and Rawekar (2017). The features are: (1) Multimedia: It allows users to have a conversation through videos, text, images, and audio or voice notes to their friends in groups and contacts. (2) WhatsApp voice messaging allows users to communicate with contacts and groups instantly. It can be used to deliver critical and time-sensitive information. (3) Group Chat: It helps the people in a social network with up to 200 group contacts. So, the students or the teachers can make a group to discuss the material in online learning. (4) Unlimited Messages: The user can share any messages on WhatsApp without any limited number. (5) Offline Messages: The messages delivered by others offline were received when they were connected to the internet. The users can read the messages without missing conversation flows. (6) Pinned message and changed Users Name: The users can put the important contacts or messages to appear in the upper chat to ease the users in interacting. (7) WhatsApp Web: It allows the users to connect their WhatsApp account to a website that can be accessed through a computer as long as they are connected. 
The features provided by WhatsApp supported the teacher and the students in online learning. It helped the expansion of teaching-learning activities online.

\section{Grammar}

Grammar has become one of the critical components of a language. It has an essential role in a language like culture and vocabulary (Outaleb, 2014). Thus, there are many definitions of grammar proposed by the expert. The study of grammar based on DontchevaNavratilova (2013) is the organization of rules and principles which underline the form and the meaning of the smallest unit of language.

Grammatical competence has a category named part-of-speech. According to Lehmann (2013), part-of-speech is a grammatical category of a word, such as noun, verb, adverb, and adjective. Part of speech is as follows:

A noun is a word-class referred to a person, animal, place, thing, abstract, or idea. The articles such as "a" and "an" are often used before mentioning nouns. Nouns are divided into singular or plural, concrete or concept. It can show possession by adding 's after the noun word. It has many different functions in a sentence. It has a role as a subject, object, and many more.

Then, a pronoun is a word class with a function to replace a noun. It is usually used for specific nouns. It is named antecedent. For example, "He is the boy." "He" in the sentence is the pronoun. Furthermore, pronouns are defined by several types: personal pronouns, which refer to specific people or things; then to refer to the ownership is possessive pronouns; reflexive pronouns have a function to highlight another noun or pronoun; relative pronouns present a subordinate clause, and demonstrative pronouns refer to or point to nouns.

An adverb is a word-class that modifies or explains a verb, an adjective, or adverb. Usually, it has a role in answering when, where, how, why, and it is often ended by -ly.

A preposition is a word placed before a noun or pronoun to modify another word in the sentence. Thus, a preposition always becomes part of a prepositional phrase that functions as an adjective or an adverb.

The conjunction has a function to help words, phrases, or clauses link. It shows the relationship between every element in the sentence. Conjunctions are divided into two, namely coordinating conjunctions that connect grammatically equal elements, such as: but, and, nor, 
or, so, for, yet, and subordinating conjunctions, which link clauses that are not equal, such as although, because, since, and while.

\section{Teaching Grammar}

According to Harmer (2007), there are two common approaches in grammar teaching: deductive and inductive approaches. The deductive approach starts explaining the language based on its rules or formula, followed by practicing exercises (Allahyar \& Ramezanpour, 2011). Students will be asked to phrase or sentence about what they have learned. This approach counts on root memorization. The exercise focuses mainly on writing and reading, while the other aspect, such as self-expression, may be ignored. DeFelice (2005) stated that the deductive approach embedded language learning based on memorizing rules or formulas.

The opposite of the deductive approach is the inductive approach. In this approach, the students who study grammar do not start the learning by knowing the formula first, but the students are given several examples of sentences. So, the students have no previous knowledge about the rules. Then, students are asked to find the formula or the pattern of its sentence (Gleason \& Ratner, 2009). The inductive approach asks the students to learn and practice the language but emphasizes the grammar rules. It leads the students to learn language based on its natural context. The weakness of this approach is its time taking. The students take a long time to formulate a sentence, or there is a misunderstanding when applying a formula to an example. The students find it difficult to formulate the rule based on the sentence example (Allahyar \& Ramezanpour, 2011; Thornbury, 1999). Even though it takes a little bit longer to understand the formula, it has been found that they will get better at remembering it, and it is memorable by knowing greater meaning because they understand from the root (Thornbury, 1999).

In this study, the LEE instructor used a deductive approach in teaching grammar through WhatsApp.

\section{LEE Online Course}

LEE is the abbreviation of Learning English Easy. This is an online course which is an additional hour for study outside the school hours. The teaching-learning process is held 
through WhatsApp using features such as group chat, voice notes, pictures, and many more. The total number of participants of this course was more than 25.000 students from around Indonesia. There were 12 batches until April 2021 and continued with different materials in every batch. LEE started the material from basic English. It was a monthly program, one month, held around two days until four days in its batch. Then, the students could rejoin the next batch with a different material. The LEE Online Course was initiated by a lecturer in Universitas Muhammadiyah Surakarta, Rhizki Amelia, because of the pandemic.

\section{TPACK}

TPACK is an extension of characterization of teacher knowledge by Shulman (1986) comprises the elements of pedagogical content knowledge or PCK to explicitly by Mishra and Koehler consider the role of technical knowledge which can contribute to effective teaching.

TPACK framework based on Mishra and Koehler (2006) is following:

Content knowledge $(\mathrm{CK})$. It refers to the material learning, such as the subject of knowledge or the target of teaching-learning, for which the teachers are responsible.

Pedagogical knowledge (PK). It refers to the teacher's knowledge about varieties techniques, methods, strategies, instructional practices to deliver the material. It helps the students to reach the target learning.

Technology knowledge (TK). It refers to the teacher's knowledge about the tools or the learning system used, whether a new technology or traditional, that can support the teachinglearning process and put together into the curriculum. Bikowski (2018) stated that technology impacts language education in the area of skills such as listening, speaking, reading, writing and its competencies such as grammatical, sociolinguistic, discourse, and strategic.

Four elements in the TPACK framework by Mishra and Koehler (2006) show the bond of three components of knowledge interrelate, produce and compel each other as follows: (1) Technological Content Knowledge (TCK) refers to the teacher's knowledge of blending the two components of TCK to make the mutual relationship between content or material and technology. (2) Pedagogical Content Knowledge (PCK) refers to a teacher's knowledge in organizing, presenting, and implementing the problem, topic, or issue to the students' ability. It is in line with the notion of Shulman (1986). (3) Technological Pedagogical Knowledge ( TCK ) 
refers to a teacher's knowledge in choosing and operating the technology related to specific pedagogy. (4) Technological Pedagogical Content Knowledge (TPACK) refers to the teacher's knowledge about the multiple relations of 3 components among technology, pedagogy, and content that ease teachers to advance the proper strategies in delivering the material to reach the target learning.

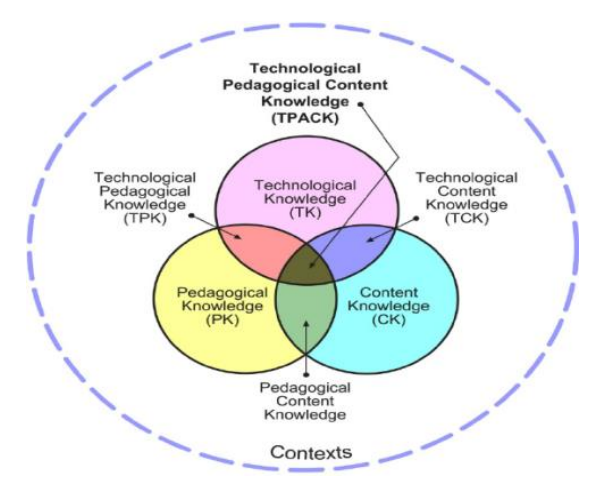

Figure 2. TPACK Diagram

The correlation between the theoretical framework above with this research can be seen that WhatsApp as a subject of technology used by LEE Online Course in this research. Pedagogical knowledge refers to learning activities by using WhatsApp. It observed the instructor's performance in the teaching-learning process and described the students' perspective of the LEE Online Course during the Covid-19 pandemic. English, precisely grammar material, is the Content knowledge of this research that the researchers dig into its implementation.

\section{Method}

The researchers used a descriptive, interpretive method to present the data. In this method, the researchers were the main point of the research in narrating and visualizing the research result. The data were collected from interviews, questionnaires, observation, and documentation to answer the research questions 1 . How is the implementation of the teachinglearning process in the LEE Online Course? 2. What is students' perception of the LEE Online Course's teaching-learning process? The founder collected the interview data all at once, the 
instructor of LEE, and the personal IT member. The interview data answered about the TPACK implementation in teaching-learning LEE Online Course. It consists of how the technology was used, how the materials were delivered, and how it was constructed.

The data from observation and documentation also supported the TPACK implementation in LEE Online Course. On August 25th and 26th, 2020, the observation was done in two days at 07.00 PM. In addition, the researchers joined 11 WhatsApp groups to synchronize the interview result and the reality. The document was in screenshot form about the interaction in the group, the voice note while explaining the material, and the picture of Adverb material was used to complete the data and answer the first research question. Those documents are divided into three aspects based on the TPACK framework. The documentation was also used to crosscheck the students' perception by copying the messages delivered into WhatsApp Group and transferring them in Ms. Word.

Then, the researchers collected the students' perceptions about the teaching-learning process in LEE Online Course to answer the second research question. The students' perception was taken by questionnaire about their opinions, written directly in the WhatsApp group. The questionnaire consisted of several questions. They were about the Learning English Easy online course identity and their perception of the LEE teaching-learning process in essay form. The total number of members in LEE Batch 4 was 2.401. However, the participants who answered the question about their perception were 397 students. It is caused by the limited time given by the stakeholder to collect the answer in 30 minutes before the group setting permission changed to Only Admin who could send a message in LEE WhatsApp Group. From the 397 participants, 262 students gave a specific opinion, and 135 students gave a perception in teaching-learning LEE Batch 4 in general or in a whole process. It is $66 \%$ compared to $34 \%$ in 397 participants.

The researchers used descriptive interpretive of TPACK framework by Mishra and Koehler (2006) as the data analysis technique. The TPACK framework consists of three elements. They are technology, pedagogical and content knowledge. In analyzing the data, the researchers divided the data into three aspects. Every aspect or element of TPACK has its code. The data distribution was done to know the percentage and the specific aspect that gives the most significant contribution of LEE Online Course in implementing the TPACK framework. 


\section{Findings}

There are four types of data collection. They are the data collected from interviews, questionnaires, observation, and documentation. Later, the researchers separated those data into three aspects, referring to the TPACK Framework by Mishra and Koehler. Those data answered the research questions 1 . How is the implementation of the teaching-learning process in the LEE Online Course? 2. What is students' perception of the LEE Online Course's teaching-learning process? The researchers observed the LEE learning process on the $25^{\text {th }}$ and $26^{\text {th }}$ of August 2020. At that time, the learning topic in LEE Batch 4 is Adverb and Adverb of Frequency. The total number of participants in that event is 2.401 students. It is divided into 11 WhatsApp Groups, consisting of a maximum of 255 members in each group. The researchers asked their opinion about the teaching-learning process in LEE Batch 4 through WhatsApp Group.

\section{Technological Knowledge}

The interview data were collected by the founder, an instructor of LEE at a time, and by one IT staff. Based on the interview, the founder informed that this program came from the pandemic situation, that everything was online, then the students got more time to stay at home and had screen time longer. She also said that the background of this program was a voluntary event. Together with her friend, Aji, as an IT staff, they made LEE Online Course for all Indonesian students for free. Even though it is free, there are several requirements to join this class. They used technology to hold this program. First, the people who want to join LEE in every batch must upload the flyer as status in their social media and share it to a minimum of two WhatsApp groups. After that, they need to screen capture the flyer, status in their social media, and the evidence of sharing the flyer into their two WhatsApp Groups. The screen captures are delivered to the IT Staff of LEE, Aji, using a format about the members' identity such as name, address, and class. If the members have fulfilled the requirement, the IT Staff will invite them to join the LEE Group. That is what makes LEE reach the students from around Indonesia.

The features of WhatsApp used by the LEE Online Course are WhatsApp Group, WhatsApp Status, Picture, Voice Note (directly or in audio form), Text Messaging, and Setting 
Permission Group Chat. WhatsApp Group is used to collect the member of LEE; it has a function as a class in offline school. WhatsApp Status is used to inform the LEE Program to the broader area, and it is used to register to be the members of the LEE Online Course for free. Picture, Voice Note, and Text helped transfer the instructor's material to the students. The last is the Setting Permission Group Chat used to control the class.

From 262 data about students' perception in specific opinion about teaching-learning process in LEE, the researchers summarized into the Diagram 1.

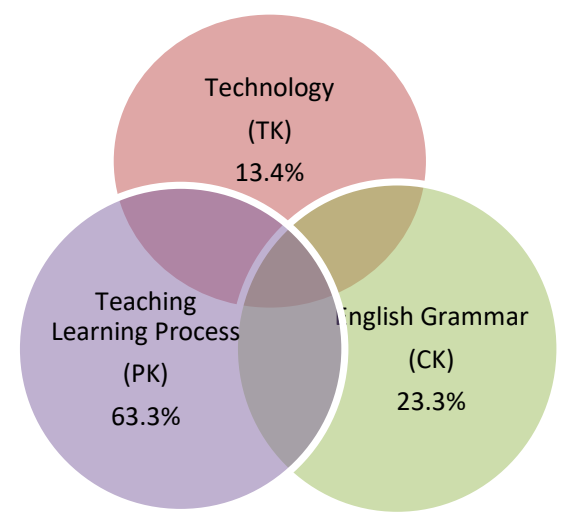

Diagram 1 Result of Students' Perception

Based on diagram 1, 35 students, or $13.4 \%$ of the total number, delivered their opinion about LEE Online Course technology. They said that they enjoy the system of the teachinglearning process in LEE. One of the participants in LEE Batch 4 said that "Since I joined LEE Batch 4, I easily study English. The explanation is very easy to understand and the situation is not too serious, and I can enjoy the study". The teaching-learning process has 2 hours duration. It is started on August 25th from 07.00 PM - 09.00 PM. The technology was fully used in the LEE Online Course, mainly the WhatsApp features. It combined audio and picture in the process. There were six pictures and thirteen voice notes in Batch 4. In addition, there were two material pictures, one trial test picture, and seven voice notes on the first day. Then the second day, there were two material pictures, one trial test picture, and six-voice notes, which had 1 - 4 minutes duration. 


\section{Pedagogical Knowledge}

Based on the observation, documentation, and interview. The instructor explained that the adverb material started in two ways. On the first day, the Adverb material was explained by showing its structure as presented in Figure 3. The picture contained several sentences and its structure in showing the Adverb form in a sentence. Then the second day was started by presenting the sentence and then the structure. The instructor used mixing languages English, Bahasa, Java, and Slang language to explain the material. She also gave motivation to her students in the opening and closing of her material. The participant from Jakarta wrote in WhatsApp Group, "The explanation from Miss Amel is understandable and in detail. She also provided examples and voice notes that can make us enjoy studying. Miss Amel is one of the English teachers who are careful and wonderful in explaining the material. The English teacher usually looks like a killer, but Miss Amel is different."

\section{Content Knowledge}

The material in LEE Batch 4 is an adverb. There were only four pictures and two trial tests for two days. The material can be seen in Figure 3.

Figure 3. Material Content Presented by LEE
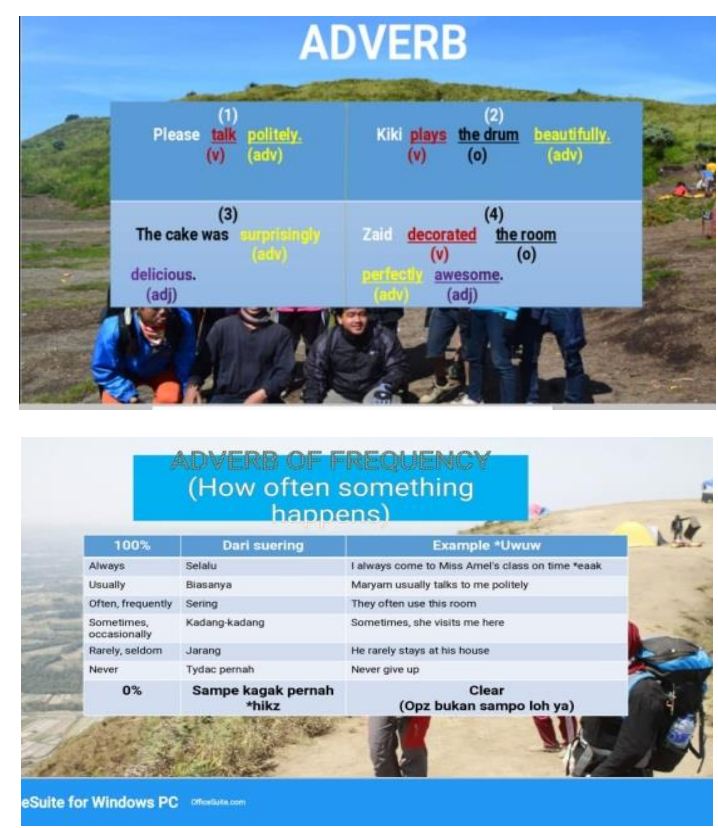

Student from Makasar, Sulawesi Selatan wrote her opinion "My experience studying English in LEE two nights makes me thankful. I can join this group, and I can improve my 


\section{Journal of Foreign Language Teaching and Learning}

Volume 7, No. 1, January 2022

Available online at: https://journal.umy.ac.id/index.php/FTL/issue/view/833

e-ISSN: 2580-2070, p-ISSN: $2527-7650$

knowledge about English even though in a short time but it is beneficial to get implemented in our daily life, the material is so satisfying, brief, compact and clear". Each material was presented only in two pictures. The material showed less than ten sentences in each picture. The first picture was the sentence with the structure; the second picture was used in Adverb material. The third picture presented trial test six until eight questions in multiple-choice form. The voice note was the explanation of the picture. The appearance teaching-learning process in LEE Online Course using voice notes and pictures in WhatsApp Group can be seen in the Figure 4.

Figure 4. Teaching-Learning Process in WhatsApp Group

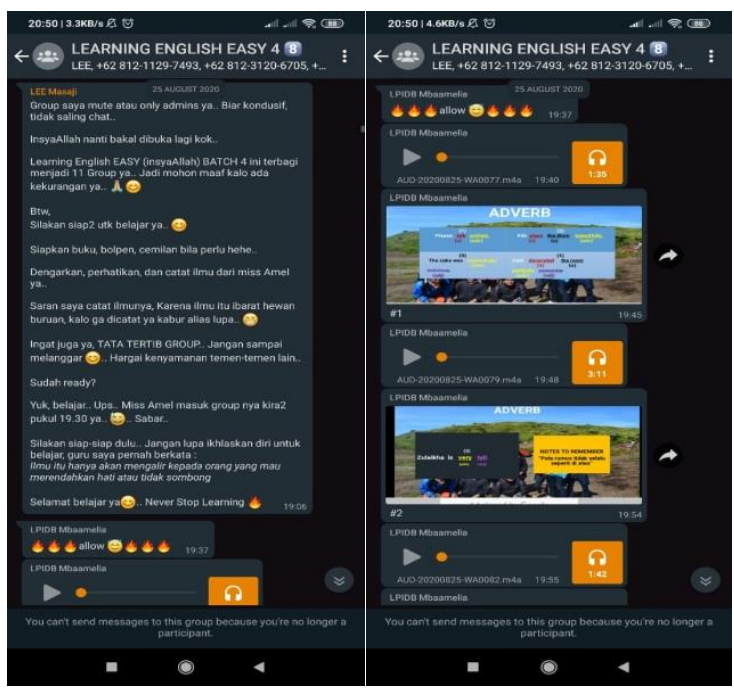

There were several students' perceptions about the instructor's explanation. A student from Purworejo, Jawa Tengah, said: "The explanation can be understood and it is not boring. I can more understand the use of Adverb". A student from Sukoharjo said, "The topic is so beneficial, and I got the motivation to not be lazy in studying English because studying English is fun and so easy to understand."

The researchers have separated the specific students' perceptions into three categories based on the TPACK Framework by Mishra and Koehler (2006) to know the percentage or the proportion of TPACK implementation in LEE Online Corse. The total number of students who emphasized in one point can be seen in Table 1 . 


\begin{tabular}{clc}
\hline \multicolumn{1}{c}{ TPACK Element } & \multicolumn{1}{c}{ The Point } & Total Students \\
\hline Technological Knowledge & The trial test presented in the picture & 3 \\
& The extraordinary use of voice notes and & 11 \\
pictures & The learning system through WhatsApp & 21 \\
& Clear explanation by the instructor & 103 \\
Pedagogical Knowledge & The teaching method is not boring & 20 \\
& Giving motivation in learning English & 23 \\
& The teaching method is interesting & 17 \\
& The great instructor's pronunciation & 3 \\
Content Knowledge & The material design easy to understand & 61 \\
\hline
\end{tabular}

Table 1. The Result of Students' Perception

\section{Discussions}

\section{Technological Knowledge}

Based on diagram 1, 35 students, or $13.4 \%$ of the total number, delivered their opinion about LEE Online Course technology. The word enjoying in that statement refers to the learning system in LEE, which uses WhatsApp as the primary tool. The learning system in LEE was held for two days only. The students enjoyed the class because of its duration, and they could study at a relaxed time at home. The class was started by introducing the topic, and there was a setting in WhatsApp Group that cannot allow the members to send messages into groups, in which Admin who could do it. It made the class under control and conducive because members could send any messages. At the same time, the teaching-learning process was blocked. Archambault and Barnett (2010) stated that Technology Knowledge in education means integrating technology into their instruction and the teacher's experience.

Moreover, the mobile phone is highly used by students (Ababneh, 2017). The feature of message permission in WhatsApp's WhatsApp group helped the teachers optimize the time using the technology. The teacher's knowledge about how to use it is needed to make it helpful 
in the teaching-learning process. In line with it, its presence starting to take place in education (Cetinkaya, 2017)

The setting' feature could engage the teaching-learning process and the features of voice notes and pictures in WhatsApp. Based on Eric (2012), the Voice Note feature or WhatsApp voice messaging allows users to communicate with contacts and groups instantly. People can use it to deliver important and time-sensitive information. As such, all voice messages are downloaded automatically. It can be used in two ways. It is directly recorded by pressing the mic button as long as the user speaks or using a recorder application from a handphone to record the material and send it to a group. The duration of Voice Note can reach for two hours directly recorded. In the LEE teaching-learning process, the instructor used pictures and voice notes to explain the material. The voice note and picture features provided by WhatsApp helped the instructor to handle 11 groups at one time. The instructor just needed one picture and one voice note, and it was delivered into 11 WhatsApp groups. By looking at the material presented in pictures and at the same time the students played the voice note, it made the students feel like studying in offline class. The pictures were used to explain the material and for a trial test. Three students gave a positive opinion about the trial test presented in a picture, and they were asked to self-correction their work by listening to the instructor's voice note.

There were $23.3 \%$ of students or 61 students pointed out the great material given by the instructor. The instructor gave simple visuals or pictures that succeeded in making the students think simply and easily. Thus, they said that the material was so brief and precise. The language used in this picture was also in Multilanguage. There were popular words in Bahasa, in English, and some languages.

\section{Pedagogical Knowledge}

The most extensive data from the students' perspective came from how the instructor explained the material. $63.3 \%$ or 166 students showed that they were satisfied with the instructor's performance in explaining the material. Based on the observation, documentation, and interview, the instructor in LEE Batch 4 used a deductive approach. The instructor explained adverbs and started explaining the language based on its rules or formula. In picture 
two, the instructor gives an example and the rules of where adverb should be and how it is in 6 ways-then followed by practicing exercises or trial tests in the end.

On the second day, the instructor used the deductive approach employed in the previous meeting. The students who studied grammar did not start the learning by knowing the formula first, but the students were given several examples of sentences. Because the material still correlates, the instructor gave a complete sentence, and the students were asked to find the formula or the pattern of its sentence. The materials were related, so it did not cost any time because they had previous knowledge background from the first night in LEE Batch 4. In this part, the instructor tried to lead the students to generalize the formula of Adverb of Frequency by emphasizing "every," "ly" at the end of "days," weeks," and "years."

The students' perception showed the excellent performance of the instructor in explaining the topic. There were six pictures and ten voice notes in Batch 4 . There were two material pictures, one trial test picture, and five-voice notes on the first day. Then the second day, there were two material pictures, one trial test picture, and five-voice notes, which had 1 4 minutes duration.

In explaining the material, the instructor used mixing languages: English, Bahasa, Java, and Slang language. The dominant language in explaining the material was the Indonesian language. Several slang words might make the students confused about its meaning, such as "Uwu" "Sorry dorry strawberry." The slang language in this context is used as an additional expression by the instructor. The language used by the instructor was also attractive and full of energy combining Bahasa and English while explaining the material. That made the students enjoy and enthusiast because they feel the interactive teaching-learning process. The instructor's consideration of mixing language was based on the students' different knowledge backgrounds. She added more about the different knowledge backgrounds based on her experience in studying English.

The motivation of combining WhatsApp use increased the students' confidence (Alqahtani, Bhaskar, Elumalai, \& Abumelha, 2018). The instructor also reminds the students to feel okay when making mistakes in English. The motivation which always comes from her is "From zero to be hero, from nothing to be something." Many students got more motivation to study English. Based on Parker et al. (2021), in the study of motivation perspective in an online 
learning environment, the student's motivation in learning is crucial because it influences their perceptions and performance. Thus, the instructor gave motivation to the students in the opening and closing of the teaching-learning process.

\section{Content Knowledge}

The students also understood the materials delivered by the instructor in the WhatsApp Group. It is shown on their trial result test at the end of the teaching-learning process. The IT Staff, Aji, firstly told about the rules in the teaching-learning process, and then the Instructor, Amel, came in using various ways such as text, including the emoticon, pictures, voice notes, and stickers. The point plus of using those features is that they can be played, viewed, and learned freely, as the students want, and with no limited time. It is automatically in the members' gallery, which can cause storage limitation but needs less signal or data usage in downloading them than the other application. Last, the combination of TPACK helped the students understand the material, and the most significant contribution of its success comes from the instructor's pedagogical knowledge. This result was supported by the research of TPACK in faculty development training on teaching, which showed improvements in their teaching effectiveness (Brinkley-Etzkorn, 2018).

\section{Conclusion and Implication}

LEE Online Course Batch 4 represented the three elements of the TPACK framework by Mishra and Koehler in their teaching-learning process. The data were taken from observation, documentation, interview, and LEE Online Course Batch 4 on August 2020. Here, LEE used WhatsApp as the primary tool in their online course. The technical knowledge is well-known by the principles. It helped in the arrangement of the material and how the instructor explained the material. The content knowledge combined with the technical and pedagogical knowledge made the students enjoy the class and gave a good outcome based on their trial test results and opinion. Combining the three elements of TPACK in the LEE Online Course could manage thousands of participants at one time. It gave satisfying responses, which were significant for education in this pandemic situation, which we can count on everything online. 


\section{References}

Ababneh, S. (2017). Using mobile phones in learning English: The case of Jordan. Journal of Education and Human Development, 6(4). https://doi.org/10.15640/jehd.v6n4a14

Allahyar, N., \& Ramezanpour, S. (2011). No extreme any more, strike a balance. Asian Social Science, 7(5), 240-243.

Alqahtani, S. M., Bhaskar, C. V., Elumalai, K. V., \& Abumelha, M. (2018). WhatsApp: An online platform for university-level English language education. Arab World English Journal, 9(4), 108-121. https://doi.org/10.24093/awej/vol9no4.7

Archambault, L. M., \& Barnett, J. H. (2010). Revisiting technological pedagogical content knowledge: Exploring the TPACK framework. Computers and Education, 55(4), 16561662. https://doi.org/10.1016/j.compedu.2010.07.009.

Barhoumi, C. (2015). The effectiveness of WhatsApp mobile learning activities guided by activity theory on students' knowledge management. Contemporary Educational Technology, 6(3), 221-238. https://doi.org/10.30935/cedtech/6151.

Bikowski, D. (2018). Technology for teaching grammar. The TESOL Encyclopedia of English Language Teaching, July, 1-7. https://doi.org/10.1002/9781118784235.eelt0441

Brinkley-Etzkorn, K. E. (2018). Learning to teach online: Measuring the influence of faculty development training on teaching effectiveness through a TPACK lens. Internet and Higher Education, 38(November 28-35. https://doi.org/10.1016/j.iheduc.2018.04.004

Burhan, A. F. (2020). Penggunaan WhatsApp dan Instagram melonjak 40\% selama pandemi Corona. https://katadata.co.id/febrinaiskana/digital/5e9a41f84eb85/penggunaanwhatsapp-dan-instagram-melonjak-40-selama-pandemi-corona

Cetinkaya, L. (2017). The impact of WhatsApp use on success in the education process. International Review of Research in Open and Distance Learning, 18(7), 59-74. https://doi.org/10.19173/irrodl.v18i7.3279

Conole, G., \& Alevizou, P. (2010). A literature review of the use of Web 2.0 tools in Higher Education. A report commissioned by the Higher Education Academy.

Dahdal, S. (2020). Using the WhatsApp Social Media Application for Active Learning. Journal $\begin{array}{llll}\text { of Educational Technology } & \text { Systems, } & 49(2), & \text { 239-249. }\end{array}$ https://doi.org/10.1177/0047239520928307.

DeFelice, B. (2005). Well-dressed English. English Teaching professional, vol. 1, 49-51. 
Dong, C., Cao, S., \& Li, H. (2020). Young children's online learning during COVID-19 pandemic: Chinese parents' beliefs and attitudes. Children and Youth Services Review. https://doi.org/10.1016/j.childyouth.2020.105440

Dontcheva-Navratilova, O. (2013). Grammar and Discourse. In Applied Linguistics. https://doi.org/10.1002/9781405198431.wbeal0464

Gleason, J. B., \& Ratner, N. B. (2009). The development of language. 7th edition. Allyn and Bacon.

Gon, S., \& Rawekar, A. (2017). Effectivity of e-learning through WhatsApp as a teachinglearning tool. MVP Journal of Medical Sciences, 4(1), 19-25. https://doi.org/10.18311/mvpjms.v4i1.8454

Harmer, J. (2007). How to teach English. Pearson Education Limited.

Jackson, E. (2012, December 3). Why selling WhatsApp to Facebook would be the biggest Mistake of Jan Koum's and Brian Acton's lives. Forbes. Retrieved from https://www.forbes.com/sites/ericjackson/2012/12/03/why-selling-whatsapp-tofacebook-would-be-the-biggest-mistake-of-jan-koums-and-brian-actonslives $/$ sh $=7 \mathrm{dd} 4885 \mathrm{cbc} 1 \mathrm{c}$

Lehmann, C. (2013). The nature of parts of speech. Second Triple International Conference, 53-92. https://doi.org/10.1524/sturf.2013.0008

Mishra, P., \& Koehler, M. J. (2006). Technological pedagogical content knowledge: A framework for teacher knowledge. Teachers College Record, 108 (6), 1017-1054

Outaleb, A. (2014). The deductive/inductive approaches to teaching grammar: Moroccan ESL university students' attitude. Mohammed V de Rabat University

Parker, P. C., Perry, R. P., Hamm, J. M., Chipperfield, J. G., Pekrun, R., Dryden, R. P., Daniels, L. M., \& Tze, V. M. C. (2021). A motivation perspective on achievement appraisals, emotions, and performance in an online learning environment. International Journal of Educational Research, 108, 101772. https://doi.org/10.1016/j.ijer.2021.101772

Robles, H., Guerrero, J., Llinás, H., \& Montero, P. (2019). Online teacher-students interactions using Whatsapp in a law course. Journal of Information Technology Education: Research, 18, 231-252. https://doi.org/10.28945/4321

Shulman, L. E. (1986). Those who understand: Knowledge growth in teaching. Educational Research, 15 (2), 4-14. 
Journal of Foreign Language Teaching and Learning

Volume 7, No. 1, January 2022

Available online at: https://journal.umy.ac.id/index.php/FTL/issue/view/833

e-ISSN: 2580-2070, p-ISSN: 2527-7650

Susilawati, S., \& Supriyatno, T. (2020). Online learning through WhatsApp group in improving learning motivation in the era and post pandemic COVID -19. Jurnal Pendidikan, 5, 852-859. http://dx.doi.org/10.17977/iptpp.v5i6.13670

Susilo, A. (2008). Exploring Facebook and Whatsapp as supporting social network applications for English learning in higher education. PDE Professional Development in Education Conference Teaching and Learning in the 21st Century, 10-24.

Thornbury, S. (1999). How to teach grammar. Longman. 